\title{
THE TYRANNY OF THE MAJORITY AND ITS REMEDIES: AN ISLAMIC OVERVIEW
}

\author{
Wan Naim Wan Mansor* and Ahmad Badri Abdullah**
}

\begin{abstract}
In modern Western political discourse, the 'tyranny of the majority' has been widely discussed as an obstacle to viable democracy. Across the years, various measures and institutional mechanisms have been developed and introduced to prevent such tyranny. Meanwhile, Islamic legal thoughtfrom legal maxims sanctioning majority interests to the concept of dhimmahappears to prioritise the interests of the majority at the expense of the minority. This article provides an overview of key aspects from the 'tyranny of the majority' discourse before enriching the discussion with a comparative study of Islamic political thought, emphasises the dynamics of majorityminority relations. While the discourse on the tyranny of the majority may inform the Islamic legal tradition about the challenges of running a plural society, Islamic principles also offer a lot of potential resources, particularly in providing moral substance and a more complex discussion of the ethics of regulation. Finally, this article proposes a win-win solution that safeguards both the welfare of the majority and the minority, thus enhancing a sense of co-existence and cooperation in society.

Keywords: Tyranny of majority, majoritarianism, religious minority, political Islam, maqāșid al-sharī'ah, 'aqd ahl al-dhimmah, 'majority rule, minority rights'.
\end{abstract}

\section{Introduction}

In the wake of Trump's controversial 2017 'Muslim' travel ban, many have become worried about the rise of institutionalised Islamophobia and fascism in the US. Proponents of Trump were quick to disseminate the notion that Islam is more political than it is religious, thus making Islam the ideological enemy of the US, supplanting the communism of the Cold War era. ${ }^{2}$ The consequence of pandering to this Huntingtonian 'clash of civilization' thesis is that it is possible by treating Islam as a political ideology (rather than a religion), warrant discrimination and subjection to extreme regulation. Specialists in political Islam posit that the underpinnings of such anti-Islamic viewpoints is the perception that Islam is inherently intolerant, anti-democratic and authoritarian. This article intends to address such perceptions, particularly in terms of majority-minority relations. 
Most Islamic scholars would agree that universal values such as freedom, equality and justice are at the heart of Islamic teachings. Accordingly, any policies or government frameworks derived from the Shari'ah should reflect these cornerstone values. Yet, the majority-minority relationship in an Islamic polity remains a difficult and often politicised subject of inquiry. Specifically, the juristic and historical concept of 'aqd ahl al-dhimmah (literally, the contract of the protected people) has become a major source of criticism, held up by some as a reflection of Islam's inherent intolerance towards minorities. Although more can be said concerning the aforementioned presumption of 'intolerance', the Islamic legal tradition does suggest a tilt in favor of majoritarian principles.

While the following of the majority might be an indication of a desire to reach a consensus and thus remain true to the principles of consultation - a universal virtue in itself-evidence suggests that the majority can advance its interests at the expense of the minority, causing injustice and mistreatment (e.g. racial discrimination, political disempowerment of the poor). If this is the case, then such majority rule is detrimental to principles of justice and mercy, which are both pillars of Islam. Would a genuine commitment to the Shari'ah allow for policies favouring the absolute interests of the majority at the expense of the minority? If the answer is negative, are there legal grounds to permit regulation to safeguard the interests of the minority? And finally, and perhaps most importantly, is there a guideline or framework that Islamic principles can offer in this matter?

A clear understanding of how Islam dictates policies involving majorityminority relations requires an ability to answer the above listed questions. Despite the various and multi-faceted definitions of 'majority/minority', ${ }^{3}$ this paper is particularly concerned with majority and minority in the religious sense, since we believe that this perspective is the most pressing concern for Muslim polities aspiring to remain true to the faith. The primary goal of this article is to develop a theoretical tool (as opposed to a one-time solution) which can guide policy-making decisions capable of balancing the rights of religious majorities and minorities.

Our discussion unfolds as follows. The first subtopic presents a review of several Islamic ratio-legal apparatuses which seem to favour majoritarianism. It concludes that despite these apparatuses, they do not necessarily support policies prioritising the majority. The second subtopic provides an overview of the concept of the 'tyranny of the majority', a phrase made popular by Alexis de Tocqueville, who intended it as a critique of American democracy. The third subtopic then discusses the 'harm' principle, which provides a complexed and nuanced account of what constitutes genuine harm, for the purpose of regulating and delineating the rights of majorities and minorities in policy-making. The fourth subtopic is dedicated to a critical review of the 'aqd ahl al-dhimmah, thereby acknowledging 
its striking visibility in this matter. This subtopic begins by studying the divergent understandings of this concept, followed by arguments on how an ahistorical approach to the ruling conflicts with the principles of justice. The subtopic then ends by concluding that the concept should not be blindly imitated at the expense of its contextual settings and primary objective. The fifth subtopic finally proposes a guiding framework to address the problem of majority tyranny by clearing up the presumed contradiction between majority and minority rights, as well as balancing its legal response (in term of austerity).

This brief study concludes that Islamic law could benefit from the 'tyranny of the majority' discussion. Shari'ah principles far from contradicting the latter, might even support it.

\section{Does Islamic Legal Theory Favour Majority Rule?}

As we shall see, there are multiple Islamic legal concepts that suggest an inherent tilt towards majority principle and majority decision-making. Sinanovic in particular supported this conclusion by listing ijmā' al-sawād al-a 'zam, jumhūr and several legal maxims (qawā' id al-fiqhiyyah) — such as "my community does not agree upon error" (lä tajtami 'u ummati 'ala dalālah) and "the general benefit predominates the individual benefit" - as relevant legal devices in favour of majoritarianism. ${ }^{4}$

Ijm $\bar{a}{ }^{\prime}$ (unanimous agreement) ${ }^{5}$ is one of the most authoritative sources of Islamic law, preceded only by the Qur'an and the Sunnah. Although ijma $\bar{a}^{\prime}$ does not directly partake in divine revelation, its role is invariably influential in Islamic jurisprudence. Technical definitions of ijm $\bar{a}^{\prime}$ vary; Al-Ghazāli defined ijmā as an agreement of the ummah of Muhammad in any religious matter; another definition often used by scholars specifies the temporal element, defining it as "an agreement among scholars of the Muslim ummah of a particular period on certain issues." ${ }^{\prime \prime}$ The primary underlying philosophy of $i j m \bar{a}$ ' as argued by Safran, rests on the assurance that the community would never agree on what is wrong. ${ }^{7}$

Another important aspect of the Islamic legal system relating to the majority principle is al-sawād al-a 'zam, a concept enshrined in the Prophet's saying:

My ummah will not agree on an error, and when you see a disagreement you have to follow the majority (al-sawād al-a zam). ${ }^{8}$

Al-Sindī asserts that since the term al-sawād al-a 'zam means the majority group, Muslims should follow the majority view among them. The rationale behind this injunction, he argues, is that majority opinion is closest to the preferred ideal of consensus and therefore a correct choice to follow in the absence of unanimous agreement. This concept is very often invoked to justify majority 
roles in the process of Islamic governance. ${ }^{9}$ Al-Qaraḍāwī, in commenting on the prophetic report, defines al-sawād al-a żam as the majority of people (jumhür al-nās), the prevailing group among them (ummatuhum), as well as the greater number of them (al-'adad al-akbar min hum). He then argues the tradition commands believers to resort to majority opinion in matters of disagreement as long as the contentious subject has no explicit supporting evidence in the Qur'an and/or Sunnah. ${ }^{10}$ It is clear, Sinanovic argues, that Muslim scholars look upon al-sawād al-a zam as testimony to the validity of majority principles in the decision-making process of an Islamic polity. ${ }^{11}$

The concept of jumhūr also resonates well with the majority principle. Jumh $\bar{u} r$ refers to the preference of the majority of scholars concerning an issue that is the subject of disagreement among Muslims. Precedence for this concept is not only found in legal disputes, but also in the mechanism for appointing the head of state. When 'Umar (RA) was nominated for the office of khalifah, the oath of allegiance was established only after the majority of the Companions (jumhür $a l-s ̣ a \bar{a} b a h)$ had unanimously agreed on the matter. ${ }^{12}$

Concerning the Islamic juridical concept of benefit (mașlahah), public interest (mașlahah al- 'àmmah) is given priority over personal interest (mașlahah al-khașsah). Al-Shatibi stated that:

where removing harm altogether is possible, removing the general harm is prioritised, and therefore causing general harm should be prevented as the public mașlahah is given priority over the private ones. ${ }^{13}$

Some relevant legal maxims are also supportive of the majority principle, such as "that which is preponderant (in greater quantity) should be ordained"; "a more probable assumption amounts to the execution"; "that which is preponderant (in greater number or quantity) is to be taken into account, and that which is rare is not to be enjoined" 14 and "the greater part gets the jurisdiction of the whole". ${ }^{15}$

The preceding arguments seek to establish that Islamic legal and political thought gives preference to majority opinion in matters regarding public affairs and social benefits. Nonetheless, these arguments may not be factually accurate as they appear to be one-sided. Another side to the argument is that the Qur'an on many occasions also warns the Believers against resorting to the majority opinion if doing so may lead whole group astray:

And if you obey most of those upon the earth, they will mislead you from the way of Allah. They follow not except assumption, and they are not but falsifying. (Al-An'ām 6:166)

This may indicate that truth is not always with the majority. A historical precedence supports this notion, namely when Abū Bakr (RA) took a minority 
opinion to wage war against those who refused to pay zakāh, in opposition to the view of the majority of the Companions. ${ }^{16}$ In the case of $i j m \bar{a}^{\prime}$, there are a lot of disputes with regard to its limitations and feasibility. Some classical scholars have held that $i j m \bar{a}{ }^{\prime}$ as defined by the jumhür ulama' is not actually feasible, prompting some of them to confine the limits of its occurrence. ${ }^{17}$ More importantly, some have even argued that the hadith most frequently quoted in support of ijmā" ("my ummah will not agree on an error"), and as suggested by 'Abduh, does not actually speak of $i j m \bar{a}$ ' as it is normally understood, nor does it sustain the notion of infallibility for the community. ${ }^{18}$ With regard to the concept of jumhūr, al-Qaradāin̄, in refuting the argument on the legal status of jihad as fard al-kifäyah, clearly maintains that the dominant juristic view is not in itself a binding authority. ${ }^{19}$ When defining the term 'al-sawād al-a 'zam' in the above mentioned hadith, Ibn Qayyim al-Jawziyyah maintained that it does not necessarily denote numerical majority since whoever holds true knowledge merits the prestige of that category even though he is but a single individual. ${ }^{20}$

Finally, with regard to the contestation between public and individual benefit, whereby the former is given preference over the latter, 'Abd al- 'Azīz Sattām offers a fresh perspective. He argues that the opposite to a general mașlahah is a general mafsadah, while the opposite of a private mașlahah is a private mafsadah. General mașlahah, Sattām further argues, cannot possibly contradict private mașlahah since the former is only qualified when it engulfs a large number of private mașlahah. In other words, a private mașlahah is a part or constituent of the general mașlahah, and a whole and its parts will never oppose one another. The more feasible way to deal with the two concepts, Sattām argues, is to give preference to the general mașlahah while ensuring the private mașlahah. ${ }^{21}$

In summing up, to simply conclude that the Islamic legal spirit rests entirely on the majority principle is factually inaccurate and untenable. Despite the seeming relation between majority opinion and the idealism of consensus, majority rule should not be exercised at the expense of other equally strong principles, much less by contradicting the higher Shar'iah provisions.

\section{Tyranny of the Majority: A Critique of Majoritarianism}

[T] hough the will of the majority is in all cases to prevail, that will to be rightful must be reasonable...the minority possess[es] their equal rights which equal law must protect, and to violate would be oppression.-Thomas Jefferson, in his First Inaugural Address ${ }^{22}$

The normative authority of the majority (vis-a-vis the minority) has been typically justified on two grounds: (a) the majority possess more enlightenment and wisdom 
than a single individual; and (b) the interests of the many are to be preferred to the interests of the few because of the larger impact they have on society. ${ }^{23}$ Yet, history has taught us that without adequate safeguards, the majority can and do turn against the minority - extreme cases include the Holocaust, the continuous sectarian persecution in Iraq, the genocide against the Tutsis in Rwanda, and more recent similar cases in Sudan, Yugoslavia and Russia. ${ }^{24}$

Thomas Jefferson and James Madison, the founding fathers of the United States, clearly expressed their wariness about the dangers of tyranny by the legislative and executive arms of government. ${ }^{25}$ Such skepticism towards democracy and its underlying principle of majority rule is nothing new; the seeds of distrust can be traced back to the Greek philosophers Plato and Aristotle. To them, absolute democracy only revealed base desires, not the most virtuous. Democracy, despite guaranteeing the expression of popular will, must also safeguard itself from power abuse and violation of basic rights. The danger of majority tyranny lies not only in the infringement of the minority's positive political rights, but more importantly in the negative sense: protection against oppression and persecution based on criterias such as ethnicity, skin colour, nationality, religion, as well as sexual identity or orientation. ${ }^{26}$

Tyranny should not be confused with unlawfulness or arbitrariness, since tyranny can (and often does) operate within lawful means, ${ }^{27}$ while arbitrariness can be exercised for the collective interests of the people. Alexis De Tocqueville, who famously coined the term "tyranny of the majority" in Democracy in America, defines tyranny as a phenomenon in which a group of people are unjustly mistreated due to their differences in comparison to the majority group in a democratic country. ${ }^{28}$ Robert Dahl defines tyranny as a deprivation of natural rights, ${ }^{29}$ while Donald Bheam defines it as deprivation of any rights, with an emphasis on social norms.$^{30}$ From the perspective of democracy, tyranny of the majority is undemocratic since it is a "systematic deprivation of both positive (participatory) and negative (protective) democratic rights by denying minorities the right to participate in governance and subjecting them to the whims of the majority." ${ }^{11}$

Alexis De Tocqueville, after travelling to the United States half a century after its formation, concluded that the majority's tyranny over political and social minorities was a constant threat to the country's democracy. Tocqueville interestingly claimed that the power of the majority surpasses all the powers that are known to the European, saying that no monarch has power so absolute that he can gather all forces of society in his hand and vanquish oppositions in the way a majority makes and executes laws.

The demographic and political make-up of a society is perhaps the primary determinant factor behind the formation of majoritarian tyranny. It is observed 
that homogenous societies sharing a relatively common religio-moral reference are more immune to a tyranny of the majority. ${ }^{32}$ Having a common religio-moral reference enables homogenous societies to be more dynamic in terms of majorityminority relations, in which the divide often shifts and transforms across time and issues. The same can not be said in heterogenous societies, where differences are relatively fixed and the religio-moral gap between the majority and minority is too large to bridge. This obvious gap, and the inherent interest politicians have in power, naturally entices the majority to tyrannise in favour of its interests, making it difficult for the minority to realise their interests. ${ }^{33}$ From a political standpoint, the majority can be said to be naturally inclined towards tyranny in circumstances where there are no safeguards or agreed principles:

states on their own generally will not volunteer to protect the human rights of the minorities if, as a result of such protection, their own powers are limited or regulated. The protection of minorities thus will be regarded as unpopular not only by the government, but also by its majoritarian constituency. ${ }^{34}$

Tyranny of the majority is something that should be prevented. Political theorists have proposed several remedies, which include: constitutionalisation of permanent rights, separation of powers, sufficient checks and balances, electoral remedies (such as proportional representation and 'staggering elections', whereby political offices are not all filled in a single election), and compliance with modern international laws. Concerning the last of these, protection of minorities from abuse by majorities is one of the highest aims of international law. One of the most widely recognised international treaties on this issue is the Prevention and Punishment of the Crime of Genocide 1948. ${ }^{35}$ The UN's International Covenant on Civil and Political Rights (1966) also defines the minimum protections of minority rights. ${ }^{36}$ Moreover, The Declaration on the Rights of Persons Belonging to National or Ethnic, Religious and Linguistic Minorities further enhances protection for ethnic, cultural and religious minorities in order to preserve their languages, belief, and culture from discrimination. ${ }^{37}$ Nonetheless, these treatises have no binding legal effects and do not offer enough of a deterrent. Nor do they address the political complexities and difficulties of a democratic country.

Finally, we end our brief exposition of the tyranny of the majority by presenting the ideal solution proposed by the Western dialectic: 'Majority Rule, Minority Rights'. The idealism of 'majority rule, minority rights' entails that the minority acknowledges the legitimacy of the majority to govern, and in return the majority safeguards the rights of minorities. Amartya Sen, the Nobel Prize winner in economics, iterated that this balance is the essence and "part of the 
total structure of democracy itself." ${ }^{38} \mathrm{~A}$ democracy in which some constituents (i.e. minorities) are not entitled to reasonable participation, or where others (i.e. majority) wield disproportionate influence, is not democratic at all. This also entails that corrective or preventative measures in regards to majority-minority relations should follow a balanced approach. Ideal corrective policies, according to Bischoff, should concern themselves with two things. First, decisions to remedy cases that (supposedly) infringe minority rights must be subjected to prior analysis based on a clear criteria (as opposed to vague or doubtful ones). In such cases, there must be sufficient evidence of tyranny so as to prevent his second concern, which is the invasion of the rights of the majority group due to inappropriate or disproportionate remedial policies.

\section{The Harm Principle and Determining the Limits of Regulation}

As discussed in the final paragraphs of the previous section, there is a need for certain regulations and remedial policies in order to prevent tyranny. However, before policy-makers can construct appropriate and proportionate legal supports or restraints, a prior definition and categorisation of 'harm' is indispensable. In the context of religious majority-minority relations, unrestricted powers conferred to the majority and the absence of safeguard principles will eventually lead to the majority suppressing the minority. Our primary concern, therefore, is creating a balance between preventing harm and promoting good. This article identifies three primary parameters found in Western literature: the imminent factor, moral subordination, and power relations.

One of the primary considerations in regulating or limiting freedom is the greater goal of acquiring the truth. Silencing (minority) opinions, according to John Stuart Mill, would be tantamount to "robbing the human race" of the opportunities to find truth and weed out falsehood. Although the emergence of false ideas will initially collide with truths, it is believed that truth will always prevail and its perception and understanding will only be reinforced by the collision:

The peculiar evil of silencing the expression of an opinion is that it is robbing the human race; posterity as well as the existing generation... If the opinion is right, they are deprived of the opportunity of exchanging error for truth; if wrong, they lose what is almost as great a benefit, the clearer perception and livelier impression of truth, produced by its collision with error. ${ }^{39}$

This is absolutely in tandem with the Islamic principles of religious freedom, such as the barring of coercion even if it is the only way to Islam. ${ }^{40}$ Nevertheless, 
there are obvious harms that could emerge out of unrestricted freedom.

John Stuart Mill's 'no harm principle' in On Liberty is more about protecting the individual than protecting the majority. It is not about protecting society from deviant individuals, but protecting individuals from the imposing majority. The types of tyranny that Mill warned against are "tyranny of the magistrate" and "tyranny of the prevailing opinion and feeling." "41 Regulation, or legal limits on individuals, are only justified when individual liberty causes harm to others: "That the only purpose for which power can be rightfully exercised over any member of a civilised community, against his will, is to prevent harm from others. " 42

In this matter, Andrew Altman proposes several ideas with regards to harmful speech. For him, the limits of free expression are dependent on the harmful outcomes that free expression could cause. ${ }^{43}$ In disapproving of the ban on Holocaust denial in Europe, for example, he argues that regulation and limitation by the state should only apply to an advocacy which is "directed to inciting or producing imminent lawlessness action and is likely to incite or produce such action." 44 'Imminence' is thereby a key component in determining harm. This entails that, although certain actions might seem mundane and reasonably harmless in and of themselves, regulation and limitation are justified in certain socio-political contexts if there is widespread violence or threat of such violence. In the case of Holocaust denial, Altman argues that it does not fulfill the 'imminent' requirement since "there is nothing approximating widespread violence against Jews in any liberal state, and there is no reason to think that Holocaust denial can make a substantial contribution to bringing about that kind of violence." ${ }^{45}$

Consider also Ishani Maitra and Mary Kate McGowan's examples of how certain speeches are justifiably regulated based on their surrounding context and the imminence of harm:

Suppose, for example, that a newspaper publishes a (false) report that a candidate for public office used to be addicted to drugs. Or that Joe tells his buddy Hank, who is drunk and known to have a violent temper, that Hank's wife has been stepping out on him. Or that Emily, a teacher in an overwhelmingly white school, tells her students that they will have to make allowances for their only African-American classmate, since African-Americans need extra time to learn. If the newspaper article convinces its readers to vote against the candidate, or if Joe's report results in Hank beating up his wife, or if Emily's announcement brings it about that her white student[s] treat their African-American classmate as a moron, then the speech in question is clearly harmful. ${ }^{46}$

In the examples above, we can see that publishing a false report, lying to a friend, or making extra allowances for learning could, in specific circumstances, 
lead to imminent harm - in this case, losing a major political opportunity, physical harm, or racial discrimination. Thus, such actions do constitute harm, making them liable and subjected to legal restraint.

Aside from defining harm based on its imminence, Altman, in his discussion of campus hate speech, argues that the criterion of 'moral subordination' is at "the heart of [the] hate-speech issue", and a form of wrong that should be targeted for speech regulation. In general, hate speech is obviously harmful, especially when it incites physical violence. But even when it does not, hate speech is also known to inflict psychological harm. This can be in the form of an "abiding feeling of fear, anxiety, and insecurity", in addition to a loss of selfconfidence and even physical problems associated with serious psychological disturbance, such as high blood pressure or higher risk of heart attack. However, banning any speech merely because it causes psychological discomfort is perhaps too sweeping, and may be detrimental to healthy public interaction. Altman is all too aware of this; for him, the criterion of 'moral subordination' treads the middle ground between excess and lax policies. For instance, calling a white American 'a monkey who belongs in the jungle' is indeed hate speech and an insult, but uttering the same to an African American goes beyond that, and may fall into the category of 'moral subordination' due to its connotative references to the violent history of Black slavery. The 'moral subordination' criterion is thus more specific and more reasonable when compared to either those who are against any kind of hate speech regulation or those who favour a blanket ban on all speech that might resemble hate speech (which can hamper free exchange of ideas). ${ }^{47}$

Our final perspective on harm brings us to the role of power. Christian F. Rostbøll in his analysis of the 2006 controversial Danish cartoons depicting the Prophet Muhammad (pbuh), argues that the prior and frequent hostility towards Islam and Muslims - even before the cartoons were released - situated Danish Muslims in a disadvantaged and weak position, thereby limiting the latter's ability to interact with the Danish majority on an equal footing. ${ }^{48}$ To Rostbøll, these relative positions of power are an integral denominator in determining harmful actions. While drawing and mocking religious figures might be acceptable to liberal norms, such actions, when directed towards an already marginalised and disenfranchised community, are tantamount to bullying and an act of arrogance. ${ }^{49}$ In a similar vein, essayist and Nobel laureate J. M. Coetzee also considers power positions to be a central factor in determining what constitutes 'offensive' in the public sphere. Coetzee adds further nuances to the discussion by pointing out the fluidity (meaning it can change hands depending on context), and multidimensionality (that there are multiple grounds of power, e.g. political, cultural, moral, numerical) of power positions. One example is how the usage of 
the term 'settler' by South African blacks to denote whites caused the whites to take offence due to their "powerless[ness]."

\section{From Ahl al-Dhimmah to al-Muwātinūn Discourse}

Avor M. Emon in his discussion of religious minorities and Shari'ah's limits of tolerance correctly observed that "the dhimmi rules often lie at the centre of debates about whether the Islamic faith is tolerant or intolerant of nonMuslims." Perhaps as a result of these, 'aqd ahl al-dhimmah has given birth to multiple contradictory narratives, for instance: the 'harmony' perspective versus the 'persecution' perspective; ${ }^{51}$ subjugation versus gentleness; ${ }^{52}$ and equality versus inequality. ${ }^{53}$ Overall, almost all modern Islamic scholarship dealing with the topic of ahl al-dhimmah share in the conclusion that this concept is bound more to history and its prevailing circumstances than a theological or divine decree. This section also takes line, providing an array of examples of 'aqd ahl al-dhimmah with a special emphasis on their historical contexts. This includes the conception of nationality, the scope of rights and obligations, the prevailing political norms, and finally tracing its evolutionary phases across time.

In the classical sense, in the subjects of an Islamic state are classified based on religious affiliation: Muslims, People of the Book, and unbelievers who do not believe in one of the heavenly revealed scriptures. Muslim males however, are the only full citizens of a Muslim polity; all others occupy either secondary citizen status or non-citizen status. ${ }^{54}$ This arrangement, however, is not necessarily discriminatory because individuals were not stripped of their deserving rights. In a society where religion was used as the primary determinant of one's nationality, religious affiliation would naturally play a vital role in delineating one's rights and obligations. ${ }^{55}$ Regulation of nationalities remains an accepted norm even to this day; modern nation states, for example, differentiate and treat their citizens differently compared to non-citizens (e.g. voting rights, tax rates and access to infrastructure).

In this context, the Compact of Madinah, in our perspective, comprises rules aimed at maintaining peace and cooperation between the multiple 'nationalities' that inhabited Madinah. It stipulated that all members of society, despite their 'nationalities' and diverse backgrounds, were subject to a set of universal values based on general principles of equality. ${ }^{56}$ Non-Muslims who committed themselves to the covenant deserved full religious freedom, personal safety, honour, freedom of work and profession, as well as property protection..$^{57}$

Nonetheless, el-Gaili argues that the dhimmi system was a manifestation of religious majoritarian tyranny. ${ }^{58}$ Perhaps the most controversial aspect of 
'aqd ahl al-dhimmah is that it levies a poll-tax, or jizyah, on the non-Muslims. In this matter, there are two justifications. Firstly, such a tax is simply a compact between the non-Muslims and the Muslims in exchange for military security and exemption from military service. ${ }^{59}$ There is much evidence to support this. For instance, taxes are only levied upon able-bodied men (not women, children, monks, and the disabled), ${ }^{60}$ are exempted in cases of military conscription ${ }^{61}$ and are returned in cases of imminent defeat due to the inability of the Muslim state to uphold its promise of security, a core element in the 'aqd ahl al-dhimmah. ${ }^{62}$ Another justification for the dhimmi rule is derived from our earlier discussion of religion as an identity 'marker' of nationality. In the pre-Islamic Near East, where tribal wars and military conquests were sociopolitical norms, conditions upon surrender often included certain arrangements, involving monetary tributes and restrictions over holding public office and inter-marriage. Such arrangements were the universal norms, and arguably a necessity in such situations. ${ }^{63}$ The Byzantine and Sasanian empires are two examples of civilisations that practiced such terms of surrender (variously denoted as pistis, fides, and melta) ${ }^{64}$

While the general reasoning behind the dhimmi rule is understandable and arguably justified, the status and treatment of non-Muslims varied greatly over time and space. The Hanafite jurists granted non-Muslims equal rights with regard to property and parts of criminal law (specifically in blood money or diyāh). Al-Shaybāni delineated guidelines for Muslims whenever non-Muslims enter a peace covenant in a Muslim community:

Muslims should not appropriate any of non-Muslims' houses and land, nor should they intrude into any of their dwellings, because they have become party to a peace covenant, and since the day of Khaybār, the Prophet's spokesman announced that none of the covenanters property is permitted to the Muslim. ${ }^{65}$

Early Muslim jurists also recognised the non-Muslims' rights to hold public office, including judge and minister. It was also unanimously agreed by classical jurists that it is a basic non-Muslim right to make laws according to their own belief systems. ${ }^{66}$

The more restrictive rulings include those pertaining to dress code and hairstyle, construction and repairing of churches and synagogues, height of houses, and use of animals. ${ }^{67}$ However, in practice, the actual situation of the dhimmis did not entirely conform to these prescribed restrictions. Leadership, economic and political circumstances played a more vital role in outlining and enforcing such rules. Throughout history, it appears that theoretical ideal formulations of dhimmi rule were dissonant with actual practice. 


\section{How Dhimmi Rule Evolved Across History}

The European colonisation of Muslim countries in the nineteenth century altered the legal status of dhimmis and their position in society. For instance, in the tanzìmāt period of Ottoman history, Muslims and non-Muslims were deemed equal in rights and the jizyah was replaced with general conscription. After the colonisation period, most written constitutions in Muslim independent states enhanced the principles of equality of all citizens regardless of religion, race or sex. In Jordan and Iran, for instance, non-Muslim and other minority groups were guaranteed a fix share of seats in parliament. ${ }^{68}$

The impact of political Islam has been a suspicion of non-Muslims, to the extent of re-imposing the dhimmi status and regulations. In Egypt, Lebanon and Iraq, Christian and Jewish minorities have often experienced harsh treatment and been forced to pay jizyah. A recent example of this is the Muslim Brotherhood Initiative of 204, stating that "religious freedom is guaranteed for the recognised monotheistic heavenly religion (People of the Book)" while other non-Muslim communities, even though they have the right to live in Egypt, are not allowed to publicly express their religious beliefs or build their own places of worship. ${ }^{69}$

In a more radical fashion, Ahmed An-Naim concludes that the reality of religious minorities in the Muslim context is as follows: 1) The status of nonMuslim religious minorities under Shari'ah is not consistent with current universal standards of human rights; 2) The current state of affairs cannot be justified by claims of Islamic cultural relativism; 3) The status of non-Muslims under Shari'ah needs to be reformed. ${ }^{70}$ In order to resolve this pressing issue, there are Muslim intellectuals who have attempted to introduce equal rights for non-Muslim minorities. However, the process requires elimination of some fiqh provisions whose function is to preserve the fix boundaries between Muslims and non-Muslims and justify the former's superiority.

Another mainstream position upholds the 'same rights, same duties' principle, proclaiming equality in the 'non-religious' domain. For scholars representing this trend, non-Muslims are to be given citizenship in an Islamic state, enjoying the right to vote and political participation, but while being debarred from the highest political, military and judicial positions.

Fahmi Huwaidi, a leading Egyptian journalist, rejects the dhimmi classification, deeming it to be a historically bound concept. He argues that non-Muslims in a Muslim polity should enjoy full citizenship (muwātinūn) rights. ${ }^{71}$ Likewise, Ghannusi's explication on the equal rights of all citizens in an Islamic polity stretch to the extent that non-Muslims should enjoy freedom of belief, may hold senior state positions, and be required to contribute to a non-discriminatory tax system, whether in the form of zakah or any other tax that benefits the state. ${ }^{72}$ Nonetheless, the muwātinūn status that is granted to non-Muslim minorities 
signifies their status as compatriots sharing the same homeland (watan) with Muslims, not as full citizens sharing similar legal and political status. ${ }^{73}$

Nonetheless, the citizenship (muwātinūn) discourse in Islamic political literature, is not yet conceptually aware of the tyranny of the majority discourse and its subsequent 'solution', majority rule and minority rights. These missing dimensions in the muwaținūn discourse prevent it from seeing the flaws of democracy, aside from its benefit as a tool of consensus building and consultation. This is more pressing since the proponents of the muwattinūn discourse pander to democracy as a platform for their proposal, but have yet to address the risk of tyranny which may result from such a political structure. Moreover, the discourse of equal citizenship still operates within the framework of a majority-minority dichotomous relationship and is unable to break such pre-conceived ideas regarding the subject matter.

\section{Striking a Win-Win Situation between Majority-Minority Rights: A Maqāṣid-based Approach}

It could be argued that the very way we have thought about the majority and minority, as ontologically opposed and mutually exclusive, creates a fundamental problem whereby the former is deemed superior to the latter. Nonetheless, this majorityminority dualism can be approached differently. It is imperative to recognise that majority-minority groups are fundamentally interconnected and mutually determining; they are not merely antagonistic, but more actually complementary and concurrent. As Auda notes, this multidimensional view complies with the overriding notion of the maqāsid al-sharì'ah, which promotes seeing opposing evidences or rulings as mutually complementary. He suggests that:

Two evidences might be in opposition in term of this one attribute, such as war and peace, order and forbiddance, standing and sitting, men and women, and so on. If we restrict our view to one dimension, we will find no way to reconcile the evidences. However, if we expand the one-dimensional space into two dimensions, the second of which is the maqasid to which both evidences contribute, then we will be able to resolve the opposition and understand/interpret the evidences in a unified context. ${ }^{74}$

As argued by many, one of the most viable solutions to a tyrannous majority, and that fulfills the abovementioned multidimensional approach, is the 'majority rule, and minority right' principle. It is interesting to note that according to this tenet, majority rule provides the most protection for minority groups, thereby fulfilling political and social equality. Under majority rule, the minority recognises that the 
majority plays a significant role in the functioning of government, deciding issues on specific circumstances. Furthermore, the minority also expects the majority to respect and more importantly, safeguard their public rights, otherwise the former is less likely to recognise or tolerate the latter's rule and decision. Therefore, majority rule presupposes minority rights and in turn minority rights are pivotal to preserving majority rule in the long run. ${ }^{75}$ In sum, we would like to propose here that a positive or enhancing feedback loop depicts this mutually supportive relationship between majority and minority rights:

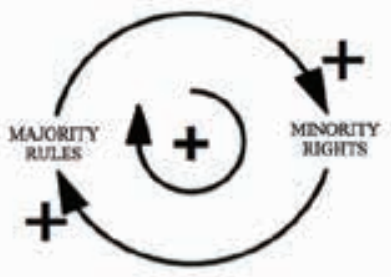

Diagram 1. Illustrating the positive or enhancing feedback loop between majority rules and minority rights.

It is important, then, for a society to forge an agreement on the extent of legitimate majority and minority rights so that they may complement each other. ${ }^{76}$ In the same vein, Sen argues that a broader understanding of democracy as a public reasoning platform, beyond mere balloting, accommodates the safeguarding of minority rights without foregoing majority preferences. For instance, democracy can eliminate famine among those who form a small proportion of any threatened population since the plight of such a minority group is politicised by public discussion, forcing the majority to prevent the famine because the general population has no reason to entertain hardened hostility towards potential famine victims. ${ }^{77}$ Furthermore, Muzaffar offers a more functional explication of the 'majority rules, minority rights' principle in the socio-economic realm, especially in the context of enhancing the dignity of religious minorities. In doing so, he argues that a state will require, among other things, i) a legal system that ensures equal protection to both the majority and minority, ii) a responsible political leadership that attempts to bridge majority and minority groups, iii) economic development that fosters social progress and guarantees equitable wealth distribution to both the majority and minority, iv) religious elites that manage to develop an inclusive understanding of religion that assists in developing affinity between the majority and minority groups, and finally v) an atmosphere which cultivates social consolation among minority group, realising the fact that their dignity and honour are imperative to the majority. ${ }^{78}$

The tyranny of the majority discourse is helpful to Islamic political thought. 
While several Islamic legal principles and a cursory understanding of shürā and $i j m \bar{a}^{\prime}$ might hint at a general inclination towards majoritarianism, there is insufficient evidence to conclude that Islam affirms the tyranny of the majority. The harm principle helps to determine the limits and targets of regulation; that excessive policies will hinder the development of truth while lax attitudes will cause considerable harm to society. All the three factors presented (i.e. imminent factor, moral subordination, power position) are arguably subsumed within the traditional five or six necessities of maqāssid al-sharī $a h .^{79}$ The Millian concern for truth, for example, can be subsumed under the preservation of intellect; the imminent factor within several darürät, such as life and property; while power relation and moral subordination can be subsumed within the preservation of honour and dignity.

The section dedicated to ahl al-dhimmah highlights the importance of critical analysis. This rule, which many refer to as the defining political arrangement espoused by Islam, must be seen from the right perspective: a political one, guided by the principles of justice found in theology. It does not go against the balanced principle of majority rule and minority rights. Blind application of the dhimmi rule without regard to current norms of social justice will only lead to the tyranny of the majority.

\section{Conclusion and Policy Recommendations}

In the current context, maqāsid al-sharì ah goes beyond the traditional protection (or promotion) of the five necessities by focusing on even higher purposes of Shari'ah, as proposed by Ibn 'Āshūr, such as equality and justice. A holistic and multidimensional approach to the matter of majority-minority relations requires us to shift our zero-sum or confrontational mindset to one that is cognizant of systemic arrangements and interconnected relationships. Developing a political structure in which majority rule is acknowledged and minority rights are enshrined ensures a more sustainable government in the long run. Thus majority and minority interests should not be framed as two opposing ends, but should be viewed as mutually inclusive, each benefitting the other. History has witnessed that the tyranny of the majority does not benefit wider society, especially in the long run. Prolonged marginalisation and disenfranchisement, for instance, might force minorities to resort to subversive ideologies as a precursor to violence and radicalism. On the flipside, it is only proper that minorities acknowledge the rule of the majority and present themselves as willing participants in wider society, not disproportionately imposing themselves and becoming tyrants themselves. This article ends with several policy recommendations: 
- It is imperative that policy-making decisions consider the substantive principles of 'majority rule, minority rights', which is a balance between two extremes. However, in terms of detailed formulations and conceptual limits, Islamic principles and the study of maqūșid al-sharì 'ah offer rich resources.

- Researchers in the field of political Islam should be cognizant of the conceptual discussions surrounding the tyranny of the majority within the context of democracy. A holistic conceptual overview of democracy, including its criticisms and flaws, enables us to offer a more informed and balanced Islamic solution--as opposed to vaguely comparing 'democracy' as a modern manifestation of shürā.

- It is imperative that Muslims have a renewed outlook on majorityminority relations, emphasising the realisation of Islamic principles in contemporary realities, rather than obsessing with enforcing classical precedents devoid of contextual awareness (i.e. 'aqd ahl al-dhimmah in a modern nation-state setting).

- Policy makers envisioning an Islamic-based governance should ensure sufficient checks and balances are built into its political and electoral infrastructure, preventing and avoiding structural tyranny towards minorities.

- The Islamic ratio-legal apparatus based on shürā and $i j m \bar{a}^{\prime}$ should not entail that the Islamic legal system favours absolute majoritarian rule. There is still room for a more balanced and tolerant approach, especially with the wealth of Islamic evidence affirming equality in the contemporary sense.

\section{Notes}

* Wan Naim Wan Mansor is Analyst at IAIS Malaysia. He may be reached at wannaim@iais.org.my.

** Ahmad Badri bin Abdullah is Research Fellow at IAIS Malaysia, with a focus on maqasid al-shari'ah (the higher objective of Shari'ah), usul al-figh, and contemporary Islamic jurisprudence discourse. He is pursuing his $\mathrm{PhD}$ in the study of maslahah. He can be contacted at badri@iais.org.my.

1. Despite not officially denoted as such, the rhetorical platform which Donald Trump stands for, and this explicit remarks that he wishes to exempt non-Muslim immigrants from the seven Muslim majority countries has made many local and international actors call it such. 
2. Michael Schulson 'The Washington Post,' Why Do So Many American Believe that Islam is a Political Ideology, Not a Religion? Available at https:/www. washingtonpost.com/news/acts-of-faith/wp/2017/02/03/why-do-so-manyamericans-believe-that-islam-is-a-political-ideology-not-a-religion/?utm term $=.55 \mathrm{ea} 2 \mathrm{e} 318614$

3. The majority and minority can be defined in relation to religion, ethnicity, social class, economic class, intra-groups, etc.

4. Ermin Sinanovic, 'The Majority Principle in Islamic Thought' Islam and Christian-Muslim Relations 15, no. 2 (2004): 238-43.

5. Mohammad Hashim Kamali, Principles of Islamic Jurisprudence (Cambridge: Islamic Text Society, 2003), 169.

6. Abū Hamīd Muhammad al-Ghazzālī, al-Mustașfā min 'Ilm al- Ușūl (Beirūt: Dār al-Fikr, t.t.), 179.

7. Nas̄ì al-Dīn al-Albānī, Silsilah al-Ahādīth al-Sahīhah, 319.

8. Abū 'Abdullah Ibn Mājah, Sunan al-Mustaşāa, Kitāb al-Fitan, Bāb al-Sawād al-A 'zam (Egypt: Al-Matba'ah al-Taziyyah, n.d.), 463-4.

9. Abū al-Hassan al-Hanāfī al-Sind̄̄, Hasyiah al-Sindī 'ala Ibn Mājah (Beirūt: Dār al-Jīl, n.d.), 464.

10. Yūsuf al-Qaraḍāwī, Min Fiqh al-Dawlah fì al-Islām: Makānatuha, mu'alimuhā, tabi 'atuhā (Cairo: Dār al-Shurūq, 1997), 143.

11. Sinanovic, 'The Majority Principle in Islamic Thought,' 242-3.

12. See Fathi Osman, 'Bai'at al-Imam, The Contract of the Appointment of the Head of an Islamic State,' in States Politics in Islam, ed. M. Ahmad (Indiana Polis: American Trust Publication, 1986), 68.

13. Abu Ishāq Ibrahim ibn Mūsā al-Shațibī, Al-Muwafaqāt fì Ușūl al-Shari 'ah, ed. 'Abd Allah Darrāz (Beirūt: Dār al-Ma' rifah, 2002), 53.

14. Muhammad Mustafa al-Zuhailī, al-Qawā id al-Fiqhiyyah wa Tatbiqatuha fi alMazāhib al-Arba 'ah (Damascus: Dār al-Fikr, 2006), 325.

15. See 'Abd al-Rahman ibn Șālih al-Qawā'id wa al-Dawābit al-Fiqhiyyah alMutadamminah li al-Taysīr (Riyāḍ: 'Umādah al-Bath al- 'Ilmī bi al-Jāmī'ah alIslamiyyah, 2003), 635.

16. Sulayman Harith Farūqū, Faruqi's Law Dictionary (Arabic- English) (Beirut: Lubnan Publishing House, 1991), 656.

17. Cf. Hashim Kamali, Principles of Islamic Jurisprudence, 182-5.

18. Muhammad Rashīd Rị̄̂ā, Tafsìr al-Qur 'ān al-Hākìm (Tafsīr al-Manār), $2^{\text {nd }}$ ed., (Cairo: Dār al-Manār, 1947), v.5, 205.

19. Yūsuf al-Qaraḍāwī, Fiqh al-Jihād: Dirasāh Muqāranah li Ahkāmihi wa Falsafatihi fi Dāru al-Qur'ān wa al-Sunnah (Cairo: Maktabah Wahbah, 2009), 406.

20. Ibn al-Qayyim al-Jawziyyah, I' lām al-Muwāqi 'in 'an Rabbil al-'Ālamin, v.3. 397.

21. See Abdul Aziz bin Sattam, Sharia and The Concept of Benefit: The Use and Function of Mașlahah in Islamic Jurisprudence (London \& New York: I.B. Tauris, 2015), 157

22. Henry Steele Commager, cited in Ahmed T. El-Gaili, 'Federalism and the tyranny of religious majorities: Challenges to Islamic Federalism in Sudan,' Harv. Int'l $L J$, no. 45 (2004): 507. 
23. Helene E. Landemore, 'Majority Rule and the Wisdom of Crowds: the TaskSpecificity of Majority Rule as a Predictive Tool.' Available at https://papers. ssrn.com/sol3/papers.cfm?abstract id=1660577 (accessed on 15 January 2017).

24. Alexis De Tocqueville, 'Majority Rule/Minority Rights: Essential Principles,' Democracy Web: Comparative Studies in Freedom. Available at http:// democracyweb.org/node/36 (accessed on: 15 February, 2017).

25. Lacy K. Ford Jr., 'Inventing the Concurrent Majority: Madison, Calhoun, and the Problem of Majoritarianism in American Political Thought,' The Journal of Southern History 60, no. 1 (1994): 33.

26. See Bruce S. Thornton, Democracy's Danger \& Discontents: The Tyranny of Majority from the Greeks to Obama (Stanford: Hoover Institute, 2014), 15.

27. See Ralph F. Bischoff, 'Minority Rights and Majority Rules,' Virginia Law Review 39, no. 5 (1953): 607-19. For example, in circumstances where the majority has absolute control over law-making processes and institutions to the extent that it favours the legal despotism of the legislator.

28. Alexis De Tocqueville, Democracy in America, trans. Eduardo Nolla, ed. James T. Schleifer, (Indianapolis: Liberty Fund, 2005), 410.

29. El-Gaili, 'Federalism and the tyranny of religious majorities,' 508.

30. Ibid., 508.

31. Ibid., 510 .

32. Ibid., 45.

33. Ibid., 510 .

34. Ibid., 511.

35. United Nation, Convention on the Prevention and Punishment of the Crime of Genocide 1948, availableonlineathttp://www.ohchr.org/EN/ProfessionalInterest/ Pages/CrimeOfGenocide.aspx (accessed on 5 January 2017).

36. United Nation, International Covenant on Civil and Political Rights 1966, available online at http://www.ohchr.org/EN/ProfessionalInterest/Pages/CCPR. aspx (accessed on 7 January 2017).

37. United Nation, The Declaration on the Rights of Persons Belonging to National or Ethnic, Religious and Linguistic Minorities 1992, available at http://www. ohchr.org/Documents/Publications/GuideMinoritiesDeclarationen.pdf(accessed on 13 January 2017).

38. Amartya Sen, The Idea of Justice (New York: Penguin Books, 2009), 352.

39. James Mooney, 'Juan Stuart Mill: The Harm Principle,' available at https:// filmandphilosophy.com/2013/03/08/john-stuart-mill-the-harm-principle/ (accessed on 29 December 2016)

40. Mohammad Hashim Kamali, Freedom, Equality and Justice in Islam (Cambridge: Islamic Texts Society, 2002), 7.

41. John M. Coetzee, Giving Offense: Essays on Censorship (Chicago: University of Chicago Press, 1996), 17.

42. Mooney, 'Juan Stuart Little,' available at https://filmandphilosophy. com/2013/03/08/john-stuart-mill-the-harm-principle/ (accessed on 5 December 2016)

43. Andrew Altman, 'Liberalism and campus hate speech: A philosophical examination,' Ethics 103, no. 2 (1993) 302-17.

44. Andrew Altman, Freedom of Expression and Human Rights Law: The Case of 
Holocaust Denial. Speech and Harm: Controversies Over Free Speech (Oxford: Oxford University Press, 2012), 34.

45. Ibid., 44.

46. I. Maitra, and M. K. McGowan, Speech and Harm: Controversies over Free Speech (Oxford: Oxford University Press, 2012), 4.

47. A. Altman, Liberalism and Campus Hate Speech, 302-17.

48. C. F. Rostbøll, 'Autonomy, respect, and arrogance in the Danish cartoon controversy,' Political Theory 37, 5 (2009): 623-48.

49. Ibid.

50. Coetzee, Giving Offense, 4.

51. Emon, 324. For the first narrative (harmony and persecution), Emon considered both to be myths, citing that the dhimmi rule is not about being tolerant or intolerant towards other religious communities, but is simply a "symptomatic [manifestation] of the more general (and shared) challenge of governing pluralistically".

52. The discussion concludes that the semantic interpretation of the Qur'an is highly dependent on the mindset of the interpreter.

53. Cf., Mohammad Hashim Kamali, Freedom, Equality and Justice in Islam, 78. Hashim Kamali, in regards to these two diverging perspectives, submits that a holistic reading of the text is required, and will suggest a strong affirmation to equality.

54. Abdullahi Ahmed $\mathrm{Na}$ 'im, 'Religious Minorities under Islamic Law and the Limits of Cultural Relativism' in Collected Essays in Law: Islam and Human Rights, ed. Mashood A. Baderin (Surrey: Ashgate, 2010), 257.

55. Tesneem AlKiek, 'Religious Minorities under Muslim Rule,' Yaqeen Institute for Islamic Research, Yaqeen Institute, 10. Available at https://yaqeeninstitute.org/ tesneem-alkiek/religious-minorities/ (accessed on 2 January 2017).

56. See Ibn al-Hisyam, al-Sirah al-Nabawiyah (Beirut: Dar al-Ihya al-Turath alArabi, n.d.), 500.

57. See Yusuf al-Qaradawi, Non-Muslims in the Islamic Society, trans. Khalil Muhammad Hamad (Indianapolis: American Trust Publication, 1996), 5-17.

58. El-Gaili, 'Federalism and the tyranny of religious majorities,' 522.

59. Kamali, Freedom, Equality and Justice in Islam, 81.

60. Cf., AlKiek, 'Religious Minorities', 14.

61. Cf., Kamali, Freedom, Equality and Justice in Islam, 91.

62. Cf., AlKiek, 'Religious Minorities,' 17. The case of Arab General and Companion Abu 'Ubaydah b. al-Jarrah.

63. M. Levy-Rubin, Non-Muslims in The Early Islamic Empire: from Surrender to Coexistence (London: Cambridge University Press, 2011), 36.

64. Ibid.

65. Muhammad ibn Ahmad al-Sarakhsi, Sharh al-Kitāb al-Siyār al-Kabir li Imām Muhammad Ibn al-Hassan al-Shaybani (Beirut: Dār al-Kitab al- 'Ilmiyyah,1997), 337.

66. See Ali Ibn Muhammad al-Mawardi, al-Ahkām al-Sultaniyyah (Cairo: Dār alFikr, 1983), 59.

67. See Ibn al-Qayyim al-Jawziyyah, Ahkām Ahl al-Zimmah (Damascus: Dār alQalam, 1997), 527. 
68. SeeArticle 64 of the Iranian Constitution. Available online athttps://berkleycenter. georgetown.edu/quotes/constitution-of-iran-article-64-representation-in-theislamic-consultative-legislature (accessed on 23 December 2015). See also Abdullah Saeed, 'Rethinking Citizenship Rights of Non-Muslims in an Islamic State: Rashid al-Ghannushi's Contribution to The Evolving Debate, Islam and Christian-Muslim Relations 10, no. 3 (1999), 317.

69. See Moataz El-Fegiery, 'Tyranny of Majority: Islamists Ambivalence towards Human Rights,' FRIDE Working Paper (Spain: FRIDE, 2012), 84.

70. Ahmed Na'im, 'Religious Minorities under Islamic Law,' 263.

71. Fahmī Huwaidī, Muwātịnūn la Zimmiyūn (Cairo: Dār al-Shurūq, 1995), 110.

72. See Rashīd Ghanūsī, Huqūq al-Muwāttanah: Huqūq Ghair al-Muslimin fì alMujtama' al-Islāmī (Herndon, IIIT, 1993), 36, 41 \& 72.

73. Gudrun Krämer et. al, "Minorities in Muslims Societies", The Oxford Encylopedia of the Islamic World, available online at http://www.oxfordislamicstudies.com/ article/opr/t236/e0536, (accessed on 15 December 2016).

74. Jasser Auda, Maqāșid as Philosophy of Islamic Law: A Systems Approach (Herndon \& Kuala Lumpur: IIIT\& Islamic Book Trust, 2010), 224

75. See Susan Welch et al., Understanding American Government (Boston: Wadsworth, 2008), 16.

76. Jamshid Gharajedaghi, Systems Thinking: Managing Chaos and Complexity, $3^{\text {rd }}$ ed., (Burlington: Elsevier, 2011), 242.

77. See Amartya Sen, The Idea of Justice (New York, Penguin Books, 2009), 352.

78. Chandra Muzaffar, Global Ethic or Global Hegemony?: Reflection On Religion, Human Dignity and Civilisational Interaction (London: ASEAN Academic Press, 2005), 59-60.

79. The five traditional 'necessities' of maqāssid al-sharīah are as follow: preservation of religion, human life, intellect, family and lineage, and property. Some scholars add a sixth: honour. 